\title{
Enacting Life-Based Learning (LBL) Approach in Quantitative Research Methodology Course: The Case of Biology Education Students
}

\author{
Herawati Susilo, Sri Rahayu Lestari, Betty Lukiati, Ahmad Kamal Sudrajat \\ Universitas Negeri Malang \\ E-mail address: herawati.susilo.fmipa@um.ac.id
}

\begin{abstract}
This study portrayed the enactment of Life-Based Learning (LBL) in quantitative research methodology course among Master's students in biology education. Literature study and action research were employed to capture data. The literature study attempted to unveil how LBL was performed. Furthermore, the action research was in the form of Lesson Study (LS) to carry out the course outline. Practically, characteristics of LBL were performed using authentic materials. These were in the forms of filling out questionnaire of first semester intake, doing peer $\mathrm{L}$, developing mind/concept mapping, assessing peers' mind/concept mapping, assessing peer portfolio, writing learning journal, doing critical analysis on journal articles, developing research proposal, assessing peers' critical analysis and performance, uploading files of mind/concept mapping, and presenting critical analysis works. From the action research lens, different-class students preferred varied strategies for similar learning materials and they favored such processes.
\end{abstract}

Keywords: Life-based learning, quantitative research methodology, biology education.

One of the tasks of lecturers is to continuously improve the quality of their performance in the teaching processes. Refining the quality of teaching should be based on the relevance of the curriculum and policies applied in the Higher Education contexts. State University of Malang (UM), for instance, have developed and compiled higher learning standards based on the National Standards of Higher Education. Learning standards developed and prepared by this university are framed or embodied in the life-based learning (LBL) paradigm (BBK UM Team, no year).

In 2016, UM was appointed as one of the four universities receiving the Islamic Development Bank (IDB) Grant. UM was designated as a center for innovative learning. In the context of developing the university as center of innovative learning, UM set life-based learning (LBL) as the basis for developing their curriculum. The curriculum developed at UM is flexible to face the challenges, which is directed at the formation of students as intact individuals who have capabilities and talents that develop in a sustainable manner (TIM BBK UM, 2016). To harmonize the lecturers' teaching practice at UM, a preliminary study to teach biology students by using a life-based learning (LBL) approach was conducted. We situated this study in a quantitative research methodology course.

We attempted to learn what, why, and how to carry out effective learning using the LBL approach and consider that LBL might be relevant to advance lecturers' teaching practices to students participating in the quantitative research methodology course since it turns out that LBL promises better results, and can help researchers solve problems that arise in lectures on the Quantitative Research Methodology. This is based on the findings of Staron (Staron, 2011; Tave NSW ICVET, 2006), suggesting that LBL endeavored to develop the capability of the individual as a whole. Another consideration is that LBL is built based on the potential of expert-based learning (work-based learning) and work-based learning (work-based learning), so that it provides a strong foundation to prepare students to learn to live (Corebima, 2016) in the sense of learning everything that is useful for future life.

For several years, the quantitative research methodology course has been taught in the first 
semester for the students. They are required to read mandatory textbooks and in groups they present the materials. At the fourth meeting, they began to search for research problems that they wanted to examine based on their research interests. Besides, they are asked to read and do a critical analysis of at least 10 articles from domestic journals (maximum 5 articles) and those from international journals (minimum 5 articles). Each of the articles they collect together with the results of their critical analysis in the form of a "Quantitative Research Practicum Report" collected periodically during the study period with the aim that the results of the critical analysis of this article are used for their research proposals. Based on the experience of evaluating research proposals submitted at the end of the study, many students did not utilize the results of the critical analysis of the article to prepare their proposals. The task of critical analysis of articles is only used as part of the collection of structured assignments of subjects as if they have nothing to do with the preparation of research proposals. The proposal they produce may also still be the result of "copy paste" from parts of the article or from the research reports of other people they merge when they have to submit their research proposal.

Another problem that we face is how to prepare students, most of whom are "fresh graduates" to study as a "whole" person, and develop their capabilities (Staron, 2011) to live in the future in the sense that as future teacher/lecturer, they can also develop the capabilities of their students (Hill, Ell, \& Eyers, 2017) since there is a tendency that the teacher or lecturer teaches their students according to their experience of how they were taught previously in university.

This study, thereby, was designed to uncover 1) the process or activity of student learning using life-based learning (LBL) approach that empowers students to learn to develop the their capabilities and the peers' and 2) models of teaching with LBL approach for quantitative research methodology course .

\section{METHOD}

\section{Research Design}

The purpose of this study was to explore how to teach Life-Based Learning (LBL) to master's students in biology education. The methods used were literature study and action research. The literature study explained the LBL and its characteristics, while the action research was to realize this approach through authentic assignments. Four quantitative research methodology courses participated in this study, with each class consisted of 18 students and only class A 19 students. The report on the process of teaching students for preliminary research was limited to the first six meetings of teaching and learning activities that take place from August 22, 2016 to September 30, 2016.

\section{RESULTS AND DISCUSSION}

\section{Results}

Authentic assignments given to students in the in the class were in the form of structured and independent assignments, namely 1) filling out the questionnaire at the beginning of the semester, 2) doing peer teaching within two LS cycles, with the first cycle emphasizes on the selection of learning strategies in accordance with the material learned and the second cycle, in addition to choosing the right learning strategy, practices developing one of the $21^{\text {st }}$ century life skills chosen by the group to be trained in how to measure it, 3) compiling and assessing mind/concept mapping of the learning material, 4) evaluating the performance of groups, 5) writing a learning journal, 6) doing critical analysis of articles from reputable journals related to research problems, 7) gradually developing the thesis research proposal from research problems, the background of research problems and literature review, research hypotheses, research designs and research procedures, development of research instruments and data collection designs, data analysis designs and development of thesis proposals, 8) assessing the results of the critical analysis and the practice of peer group activity, and 9) uploading mind/concept mapping file, presentation, and learning journal at the specified time. 
At the first meeting, the students were asked to fill in the preliminary questionnaire which contained the student identity, reasons for taking the course, the expected competency, the expected capabilities, desired value, ways or efforts to achieve this value, self character that supports success in learning, desirable teaching and learning activities, the book of quantitative research, and other suggestions for lectures. In addition, the course outline of quantitative research containing authentic assignments is expected to develop the 21 st century life skills of the students participating in this course. Students are asked to criticize the course outline presentation, with the hope that they provide input for its improvement. Additionally, the students were divided into groups consisting of 3 or 4 students. Each group formed a face to face professional learning community (Learning \& Kimberly, 2010) and they were assigned to discuss two topics of learning materials. Each group criticized the contents of the material and selected the most appropriate learning strategy for each material, so that the quantitative research learning is not a "No Name Learning" (Corebima, 2016). In the second task, in addition to choosing the right learning strategy for the material learned, they were also asked to develop one of the life skills in the peer lesson study activity. The $21^{\text {st }}$ century life skills that they can develop might be critical thinking skills, problem solving, communicating, collaborating, and creating and innovating (Trilling \& Fadel, 2009) accompanied by instruments to measure the achievement of life skills. The $21^{\text {st }}$ century life skills developed by the students can also be in the form of thinking skills (critical, creative, metacognitive), acting skills (communication, collaboration, ICT), life skills (adapting, leading and leading, and continuing studies or preparing for work) (Greenstein, 2012).
Prior to the presentation, students were asked to consult the selected learning strategy to the lecturer (Plan). In Do activity, the two peers observed the learning. Afterwards, a See activity was carried out in the classroom by asking the model lecturer to reflect on the learning. The peers were also asked to comment on the learning process they were experiencing. Different learning strategies were selected by different groups of students in different classes. Quantitative research methodology material taught includes the Nature of Research, Research Instruments, Research Problems; Literature Review, Research Design, Research Proposal, Descriptive Research, Experimental Research, Factual Exposure Research, Action Research, Statistics for Data Analysis, and Reporting Research Results. Students were asked to select the most appropriate learning strategy for the material that is part of the group learning. Students were also asked to prepare lesson plans for material that their groups will enact, then in small group discussions (as Lesson Study Teams), they selected one that will be used as a model lecturer and discuss the lesson plan results of group development with the lecturers as a team supporting lecturers for the quantitative research course in the framework of the Plan Lesson Study for the next course outline that has been refined based on the results is implemented in the classroom (Do Lesson Study) and after learning discussion (See Lesson Study).

In practice, not all student groups discuss the lesson plan with the research team, there are groups that discuss the lesson plan with a member of the research team, and there are student groups that discuss the lesson plan with two lecturers who are members of the research team, although the discussion cannot be concurrent (self-consultation with each member of the research team). Table 1 portrays the opted learning strategies by the students.

Table 1. Learning Strategies Selected by Students

\begin{tabular}{|c|c|c|c|c|}
\hline Topics & Class A & Class B & Class C & Class D \\
\hline Nature of Research & Discovery Learning & Inquiry & Study Cycle and TPS & Discovery Learning \\
\hline Research Instruments & Cooperative Jigsaw & $\begin{array}{l}\text { Problem Based } \\
\text { Learning }\end{array}$ & Discovery Learning & Cooperative Jigsaw \\
\hline Research Problems & Discovery Learning & Guided Inquiry & $\begin{array}{l}\text { Problem Based } \\
\text { Learning }\end{array}$ & $\begin{array}{l}\text { Problem Based } \\
\text { Learning }\end{array}$ \\
\hline Literature Review & Cooperative Jigsaw & Demonstration & $\begin{array}{l}\text { Number Head } \\
\text { Together }\end{array}$ & $\begin{array}{l}\text { Problem Based } \\
\text { Learning }\end{array}$ \\
\hline
\end{tabular}


From Table 1, it can be seen that there are a variety of strategies selected by the students in four classes. In determining the opted strategy, there are groups of students who consult with the research team regarding the accuracy of the selected strategy, but there are also groups of students who do not consult with the research team. When we asked why the strategy was opted, they generally contended that, according to them, that strategy is what they think is most appropriate for learning the material. There is a group of students in class $\mathrm{C}$ who then choose another strategy to teach the material "Research Tools" that they have learned to their friends because they feel that the strategy they have selected, namely Discovery Learning, is not appropriate to learn the material being taught. Of course the student group was unable to repeat their learning, the group then prepared a Learning Implementation Plan for the material with the "Cooperative Jigsaw" strategy.

Based on the results of the student action research participants in the quantitative research course it is still difficult to choose the right learning strategy for the material to be learned. This is not a problem for researchers, because one of the goals of researchers asking students to teach their friends with one of the strategies selected is so that students know, choose, and try (and for their friends who are taught, experience learning to use) various learning strategies that they can choose in their future research.

There is a possibility that the strategy selected by the students is still not appropriate in its application, this is also not a problem for researchers, because that's where the students get the opportunity to observe how the implementation of a strategy is correct.

Another problem related to this strategy is how to assess whether the learning strategy selected by students is appropriate or not. The accuracy of the selection of a strategy depends on the learning objectives to be achieved, the ability of the lecturer who teaches it, and the ability of students to learn, in addition to the completeness of the required infrastructure.

\section{DISCUSSION}

\section{Life-Based Learning}

Life- Based Learning (LBL) recognizes various learning resources, which open up opportunities to develop abilities (Staron, Jasinski, $\&$ Weatherley, 2006). Life Based Learning focuses on learning from one's entire life at any point in time and the source of that learning (Staron, 2011). Characteristics of BBK developed by MEs consist of 10 aspects, namely 1) emphasizing the development of the capabilities and talents of students, 2) developing the intact personality of students as students, 3 ) promoting orientation based on autonomy and independence of students, 4) recognizing various sources of learning as a place of learning student subject learning, 5) balance between integrity and usefulness of learning for students, 6) recognize that students are very responsive to their own learning, 7) place the learning organization or community interrelated, related, and embracing, 8) recognize the contradictions and errors that are occur in praxis learning as the dynamics and strength of learning so that it must obtain a space of recognition in learning, 9) placing human will and enthusiasm as a critical point that is very important in the success of learning on an ongoing basis, and 10) recognizing the process of change or learning progress qualitatively varies between subjects students (TIM BBK UM, 2016). The relationship between structured assignments and Life Based Learning characteristics can be seen in Table 2.

\section{Table 2. Relationship between structured assignments and life-based learning characteristics}

\begin{tabular}{ll}
\hline $\begin{array}{l}\text { Authentic Materials } \\
\text { Assignments }\end{array}$ & $\begin{array}{l}\text { Life-Based Learning } \\
\text { Characteristics }\end{array}$ \\
\hline Filling out questionnaire & 6,9 \\
\hline Developing Mindmap & 4,10 \\
\hline Doing peer Lesson Study & $1,3,7,8,9$ \\
\hline Developing learning journal & $5,6,10$ \\
\hline $\begin{array}{l}\text { Doing critical analysis on } \\
\text { article journal }\end{array}$ & 4 \\
\hline $\begin{array}{l}\text { Doing group discussion } \\
\text { and presentation }\end{array}$ & 5,7 \\
\hline Writing research proposal & $2,3,4$ \\
\hline
\end{tabular}




\section{Capability Enhancement}

The development of student capabilities is carried out by providing authentic lecture assignments. The results of the research that are expected to appear theoretically in the cognitive field are conceptual understanding of quantitative research methods, in the affective field is the willingness to provide the best service in teaching peers in peer teaching through Lesson Study practices by compiling lesson plans, discussing lesson plans with friends and coaches of the course (Plan), implementing lesson plans in the classroom (Do), and reflecting on learning in class (See), in the field of skills in the form of skills to design, teach, and reflect on activities to teach friends in peer teaching and observing skills his friends learn as LS observers. The following discussion is carried out by discussing the ten authentic tasks given, by presenting the purpose of assignment, what aspects of life skills of the 21st century are developed through these authentic tasks and justifying the reasons for their use.

\section{Filling Out First-Semester Intake Questionnaire}

The completion of the questionnaire at the beginning of the semester is intended to develop students' metacognitive skills, that is, so they think why they are taking this course, what grades they want to achieve, how they plan their learning or learn how to learn (Suto, 2013) in order to achieve that value. Students are also forced to think about how to make lectures in class not just fun (making them entertained) but more importantly fun (making them engaged).

\section{Peer Learning through Lesson Study}

This activity develops creative thinking skills, which is to choose Learning Strategies that are appropriate to the Quantitative Research Methodology Material which is the responsibility of the group. Researchers assign students to practice learning their peers by using learning strategies that are suitable so that they are familiar with the various learning strategies available and can be selected from the beginning, because each learning strategy is developed with specific goals. According to (Corebima, 2016) it fulfils lecturers' accountability demand.
The fact that there are variations in the choice of Learning Strategies for the same material shows that through this lecture several principles of life-based learning have been applied according to Staron (2011) demonstrate recognition and giving space for students as their own practical praxis designers without violating applicable general rules. There are also variations in the effectiveness of learning outcomes due to differences in the learning process/learning experience.

This activity also develops acting skills to form a Professional Learning Community (PLC) (Gunawan, 2017; Susilo, 2013). Collaborative activities between educators are still very rare, therefore in this course they are trained in the form of collaborating with LS teammates to design a lesson plan (Plan), making presentations in the implementation of the lesson plan (Do), and selecting and using learning media that is suitable with the material being learned, and assessing the effectiveness of the learning strategies selected to achieve the learning objectives (See). Lesson Study activities can also be used to improve the learning process (Sudrajat, 2017).

The assignment of doing Lesson Study in this peer teaching activity was also used in developing collaborative and life skills, in the form of skills to adapt, lead and to-be led, and prepare for the workforce (Greenstein, 2012). Adaptation skills are trained through the exchange of roles as students who teach and those who learn, who lead and are led. The skills to prepare themselves for the world of work are trained in the form of all the tasks that equip them to achieve the learning outcomes as expected through lecturing the research methods they are taking.

the results of this preliminary study are in the form of course outline and quantitative research methodology practicum instructions whose learning is based on life, mandatory text book adaptation by students which theoretically can be used as material for prospective educational research methods textbooks; student presentation file regarding the contents of the mandatory textbooks, and experience managing lectures on the quantitative research methodology which is carried out to study studentbased learning. 
The results of other studies that support the implementation of this research are the experience of researchers in guiding biology students at the undergraduate, graduate, and doctoral levels. In the mentoring, the researcher with the students participate in developing and thinking about how to develop $21^{\text {st }}$ century life skills, what theories are underlying them, and how to measure them. Some of the results of these studies have been published in the form of articles in international journals. The $21^{\text {st }}$ century life skills developed and researched by students include the ability to think creatively through learning the Low Level of Inquiry model (Fatimah, Susilo, \& Diantoro, 2016), the ability to think creatively through project based learning (Maghfiroh, Susilo, \& Gofur, 2016), creative thinking skills through inquiry learning combined with PjBL; critical thinking skills through Argument-Driven Inquiry (Hasnunidah, Susilo, Irawati, \& Sutomo, 2015), critical thinking skills through inquiry learning (Triyanto, Susilo, Rohman, \& Lestari, 2016) and critical thinking skills through Socio-Biological-Case Based Learning (Pratiwi, Suwono, \& Susilo, 2015). In addition there are students who develop information literacy, science literacy, and critical thinking skills of students through Blended-Challenge-based Learning (Saefi, Suwono, \& Susilo, 2017). During the years of teaching quantitative research methodology courses, researchers also did not intentionally and planned to learn to develop one or several $21^{\text {st }}$ century life skills in students themselves that researchers learned through the educational research methodology course. Meanwhile, in guiding students to prepare their thesis, or thesis, or dissertation, researchers always suggest that students try to develop one or more life skills of the $21^{\text {st }}$ century in the students they learn through their research (Akhiruddin, Susilo, \& Ibrohim, 2016; Fatimah et al., 2016; Hasnunidah et al., 2015; Maghfiroh et al., 2016; Pratiwi et al., 2015; Triyanto et al., 2016). Therefore, in giving assignments to teach their friends, researchers also ask students to practice developing one of the $21^{\text {st }}$ century life skills of their friends and practice doing assessments to assess the results of their development.

This activity also trains students to be skilled in life that is able to adapt to be leaders and who are led, trained in the form of adapting activities as model lecturers, observers, or students in peer teaching, namely practicing leading and being led.

\section{Developing Mind/Concept Mapping}

Students who are not on duty teaching their friends are assigned to develop Mind Maps (Classes A and B) or Concept Maps (Classes C and D). The purpose of this assignment is that the Quantitative Research Methodology lecture process runs smoothly, because the students who will be taught by their friends have prepared themselves to learn the material learned that day. This mind map and concept map were assessed by a group of friends using an agreed rubric.

A mind map developed by Buzan in 1970 (Buzan, 2018) is an expression of thinking activities. According to Buzan (2018) mind maps can be used for various activities related to the mind, namely thinking, recalling, designing, and creating. Furthermore Buzan (2018) states that mind maps are drawing techniques that can provide a universal key to unlocking the potential of the brain. Mind maps can be applied to every aspect of life where learning will be better and thinking more clearly will improve performance. Mento \& Jones (1999) proved the importance of the role of mind maps in learning their students.

The concept map introduced by Novak in 1984 was also trained in its use to compare the results with the use of mind maps. Theoretically concept maps have advantages and disadvantages compared to mind maps (Eppler \& Usi, 2006), so it is advisable to check the effectiveness of both uses by conducting experimental research.

\section{Doing Critical Analysis on Journal Articles and Writing Research Proposal for Quantitative Research methodology}

This activity was assigned to develop students' critical thinking skills, namely to conduct induction and deduction in the context of developing quantitative research proposals as one of the final tasks of lectures. Critical thinking skills are developed through the assignment of conducting critical analysis of articles related to issues of interest to develop research proposals, and practicum development of thesis proposals in stages related to research problems, background problems 
and literature review, research hypotheses, research designs and procedures, development instruments and design of research data collection, design of research data analysis and development of proposals in full.

This assignment is also carried out in order to develop problem-solving skills that are preceded by selecting a research problem to be developed into a research proposal; analyze alternative solutions to problems; and make decisions about how to solve problems in the form of developing quantitative research proposals.

\section{Assessing Critical Analysis Works and Peer Assignments}

The exercise to assess LS groups who teach them and provide input to each other on the results of practicum development of research proposals quantitative research methodology is conducted to practice life skills as an activity to become lecturers.

The activity of evaluating practicum results in the context of developing quantitative research proposals is also intended to practice critical thinking skills that are defined as specific abilities which include analyzing arguments, claims, or evidence, making conclusions using inductive or deductive reasoning, identifying and analyzing problems, finding and evaluating problems relevant information for making decisions or solving problems and reaching appropriate conclusions (Lai, 2012; Watson \& Glaser, n.d.).

\section{Developing Learning Journal}

This learning journal is carried out to develop metacognitive skills (Haryani, Masfufah, Wijayati, \& Kurniawan, 2018; Nurajizah, Windyariani, \& Setiono, 2018; Septiyana, Prasetyo, \& Christijanti, 2012; Yulianingtyas, Budiasih, \& Marfuah, 2017), namely that students consciously think about learning how to learn (design learning activities, including how to manage time to prepare activities to teach their peers, consult with lecturers about the learning strategies selected for the quantitative research methodology material which is their group's task, create learning journals , compiling mind/ concept mapping, conducting critical analyzes of reputable journal articles, and conducting practicum developing quantitative research proposals.

\section{Uploading Files of Mind Mapping, Presentation, and Learning Journal}

This activity is trained as an effort to develop acting skills in using Information Technology (IT). Students are trained to upload learning material to be taught, presentation media such as videos and power point slides used in class, learning journals, mind/concept mapping, and critical analysis of journal articles (Critical Analysis) to Edmodo Group Class. Students are also trained to upload files at Edmodo if necessary.

\section{Enacting Group Discussion and Presentation}

Giving the task of carrying out group discussion activities in designing strategies of peer teaching in Plan activity and presenting the results of group discussions is an effort to develop student communication skills (Prozesky, 2000). This communication skill is one of the learning and innovation skills which is also expected to be developed in the 2013 curriculum as one of the 4Cs formulated by the partnership for the $21^{\text {st }}$ century (Partnership For 21 st Century Skills (P21), 2009).

\section{CONCLUSION}

This study concludes that, theoretically, through authentic assignments in quantitative research methodology, the LBL approach can be used to develop the capabilities of Master's students. The authentic task given can be formulated to become a learning strategy called REMAD COCOPER which consists of REading, (Mind or Concept) MApping, Discussing, Cooperating, Cooperative-learning, Presenting, Elaborating, and Reflecting).

Based on the findings of this study, further research is encouraged to examine the effectiveness of the REMAD COCOPER learning strategy in developing critical thinking skills and information literacy through quasi-experimental research. 


\section{REFERENCES}

Akhiruddin, Susilo, H., \& Ibrohim. (2016). Pengaruh Penggunaan Modul Inkuiri Dipadu PJBL Berbahan Ajar Potensi Lokal Terhadap Keterampilan Proses Sains Siswa SMA. Jurnal Pendidikan: Teori, Penelitian, Dan Pengembangan, 1(10), 1964-1968.

Buzan, T. (2018). Mind Map Mastery. London: Watkins Publishing.

Corebima, A. D. (2016). Pembelajaran Biologi di Indonesia Bukan untuk Hidup. Makalah Utama Pada Seminar Nasional XIII Biologi, Sains, Lingkungan, Dan Pembelajarannya Di Pendidikan Biologi FKIP UNS, Solo (6 Agustus 2016), 1-26.

Eppler, M. J., \& Usi, L. (2006). A comparison between concept maps , mind maps , conceptual diagrams , and visual metaphors as complementary tools for knowledge construction and sharing Correspondence :, (April), 202-210. https://doi.org/10.1057/palgrave.ivs.9500131

Fatimah, F., Susilo, H., \& Diantoro, M. (2016). Keterampilan Proses Sains Siswa Kelas VII dengan Pembelajaran Model Levels of Inquiry. Jurnal Pendidikan: Teori, Penelitian, Dan Pengembangan, 1(9), 1706-1712.

Greenstein, L. (2012). Assessing 21st Century Skills: A Guide to Evaluating Mastery and Authentic Learning. Singapore: SAGE Publication.

Gunawan, I. (2017). The Implementation of Lesson Study Based Learning Management and the Effect toward Students' Activeness in Lecturing. Jurnal Pendidikan Dan Pembelajaran, 24(2), 51-63.

Haryani, S., Masfufah, Wijayati, N., \& Kurniawan, C. (2018). Improvement of metacognitive skills and students' reasoning ability through problembased learning. Journal of Physics: Conference Series, 983(1). https://doi.org/10.1088/1742$6596 / 983 / 1 / 012174$

Hasnunidah, N., Susilo, H., Irawati, M., H., \& Sutomo, H. (2015). Argument-Driven Inquiry with Scaffolding as the Development Strategies of Argumentation and Critical Thinking Skills of Students in Lampung, Indonesia. American Journal of Educational Research, 3(9), 11851192. https://doi.org/10.12691/education-3-9-20
Hill, M. F., Ell, F. R., \& Eyers, G. (2017). Assessment Capability and Student Self-regulation: The Challenge of Preparing Teachers. Frontiers in Education, 2(May). https://doi.org/10.3389/feduc.2017.00021

Lai, E. R. (2012). Assessing 21 st Century Skills : Integrating Research Findings National Council on Measurement in Education, (April).

Learning, O., \& Kimberly, W. (2010). Blended Teaching and Learning, 67(Aprii), 16-21.

Maghfiroh, N., Susilo, H., \& Gofur, A. (2016). Pengaruh Project Based Learning terhadap Kerampilan Proses Sains Siswa Kelas X SMA Negeri Sidoarjo. Jurnal Pendidikan, 1(8), 1588-1593.

Mento, A. J., \& Jones, R. M. (1999). Mind Mapping in Executive Education: Applications and Outcomes, 18(4).

Nurajizah, U., Windyariani, S., \& Setiono, S. (2018). Improving students' metacognitive awareness through implementing learning journal. Jurnal Pendidikan Biologi Indonesia, 4(2), 105-112. https://doi.org/10.22219/jpbi.v4i2.5788

Partnership For 21st Century Skills (P21). (2009). P21 Framework Definitions, 1-9. Retrieved from http://www.p21.org/documents/P21_Framewor k_Definitions.pdf

Pratiwi, H. E., Suwono, H., \& Susilo, H. (2015). Pengaruh Model Pembelajaran Socio-Biological Case Based Learning Terhadap Keterampilan. Jurnal Pendidikan Biologi, 7(1), 22-30.

Prozesky, D. R. (2000). Communication and effective teaching. Journal of Community Eye Health, 13(35), 44-45.

Saefi, M., Suwono, H., \& Susilo, H. (2017). Studi Komparatif Tiga Strategi Pembelajaran Ditinjau dari Kemampuan Berpikir Kritis Mahasiswa Biologi. Jurnal Pendidikan: Teori, Penelitian, Dan Pengembangan, 2(5), 637-645. Retrieved from http://journal.um.ac.id/index.php/jptpp/

Septiyana, K., Prasetyo, A. P. B., \& Christijanti, W. (2012). Jurnal Belajar Sebagai Strategi Berpikir Metakognitif pada Pembelajaran Sistem Imunitas. Unnes Journal of Biology Education, 1(3), 109-115.

Staron, M. (2011). Life-based learning model - a model for strength -based approaches to capability development and implications for personal 
development planning Maret Staron. Mindful Creations, February, 1-14.

Staron, M., Jasinski, M., \& Weatherley, R. (2006). Life Based Learning in Attendance.

Sudrajat, A. K. (2017). Meninjau Lesson Study Sebagai Sarana Pengaplikasian Kurikulum 2013. Pros. Seminar Pend. IPA Pascasarjana UM, 2, 390 395.

Susilo, H. (2013). Lesson Study sebagai sarana meningkatkan kompetensi Pendidik. Seminar Dan Lokakarya PLEASE, 28-34.

Suto, I. (2013). 21 st Century skills : Ancient , ubiquitous , enigmatic ?, 1-28.

Tave NSW ICVET. (2006). Development Learner as Life Based Learning: a model for integration, growth and potentiality . C TAFE NSW ICVET, 5.
TIM BBK UM. (2016). Naskah Akademik BBK UM. Malang: Universitas Negeri Malang.

Trilling, B., \& Fadel, C. (2009). Twenty First Century Skills. Book.

Triyanto, S. A., Susilo, H., Rohman, F., \& Lestari, E. S. (2016). Kecakapan Berpikir Kritis dan Literasi Ilmiah Siswa Kelas XI IPA 7 SMAN 1 Karanganyar. Seminar Nasional Pendidikan Dan Saintek, 2016, 803-808.

Watson, G., \& Glaser, E. M. (n.d.). Watson-Glaser Short Form Manual. 2012.

Yulianingtyas, E., Budiasih, E., \& Marfuah, S. (2017). Pengaruh Penggunaan Junal Belajar dalam Model Pembelajaran Learning Cycle 6E Terhadap Kesadaran Metakognitif Siswa SMAN 8 Malang Pada Materi Redoks. Jurnal Pendidikan: Teori, Penelitian, Dan Pengembangan, 2(5), 724-730. 